\title{
The role of sclerostin and dickkopf-1 in oral tissues - A review from the perspective of the dental disciplines [version 1; peer
}

\section{review: 2 approved]}

\author{
Mohammad Samiei1-3, Klara Janjić (iD)2,3, Barbara Cvik|2,3, Andreas Moritz2,3, \\ Hermann Agis (iD) 2,3 \\ ${ }^{1}$ Department of Endodontics, Faculty of Dentistry, Tabriz University of Medical Sciences, Tabriz, Iran \\ ${ }^{2}$ Department of Conservative Dentistry and Periodontology, University Clinic of Dentistry, Medical University of Vienna, Vienna, \\ 1090, Austria \\ ${ }^{3}$ Austrian Cluster for Tissue Regeneration, Vienna, 1200, Austria
}

V1 First published: 30 Jan 2019, 8:128

https://doi.org/10.12688/f1000research.17801.1

Latest published: $30 \mathrm{Jan}$ 2019, 8:128

https://doi.org/10.12688/f1000research.17801.1

\begin{abstract}
Wnt signaling is of high relevance in the development, homeostasis, and regeneration of oral tissues. Therefore, Wnt signaling is considered to be a potential target for therapeutic strategies. The action of Wnt is tightly controlled by the inhibitors sclerostin (SOST) and Dickkopf (DKK)-1. Given the impact of SOST and DKK-1 in hard tissue formation, related diseases and healing, it is of high relevance to understand their role in oral tissues. The clinical relevance of this knowledge is further underlined by systemic and local approaches which are currently in development for treating a variety of diseases such as osteoporosis and inflammatory hard tissue resorption. In this narrative review, we summarize the current knowledge and understanding on the Wnt signaling inhibitors SOST and DKK-1, and their role in physiology, pathology, and regeneration in oral tissues. We present this role from the perspective of the different specialties in dentistry, including endodontics, orthodontics, periodontics, and oral surgery.
\end{abstract}

\section{Keywords}

Sclerostin, Dickkopf-1, Wnt Pathway, Regeneration, Periodontology, Endodontology

\section{Open Peer Review \\ Approval Status \\ 2 \\ version 1 \\ 30 Jan 2019

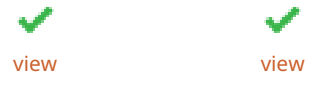 \\ 1. Francisco Javier Rodríguez-Lozano (D), \\ University of Murcia, Murcia, Spain \\ 2. Qiming Jin, University of Michigan, Ann \\ Arbor, USA \\ Any reports and responses or comments on the article can be found at the end of the article.}


Corresponding author: Hermann Agis (hermann.agis@meduniwien.ac.at)

Author roles: Samiei M: Conceptualization, Investigation, Methodology, Validation, Visualization, Writing - Original Draft Preparation, Writing - Review \& Editing; Janjić K: Conceptualization, Investigation, Methodology, Project Administration, Supervision, Validation, Writing - Review \& Editing; Cvikl B: Conceptualization, Funding Acquisition, Investigation, Methodology, Resources, Validation, Writing Review \& Editing; Moritz A: Conceptualization, Investigation, Methodology, Resources, Supervision, Validation, Writing - Review \& Editing; Agis H: Conceptualization, Funding Acquisition, Investigation, Methodology, Project Administration, Resources, Supervision, Validation, Visualization, Writing - Original Draft Preparation, Writing - Review \& Editing

Competing interests: No competing interests were disclosed.

Grant information: We thank the European Society of Endodontology (ESE) for financial support of our research [ESE research grant 2015]. The authors deny any conflict of interest.

The funders had no role in study design, data collection and analysis, decision to publish, or preparation of the manuscript.

Copyright: @ 2019 Samiei $\mathrm{M}$ et al. This is an open access article distributed under the terms of the Creative Commons Attribution License, which permits unrestricted use, distribution, and reproduction in any medium, provided the original work is properly cited.

How to cite this article: Samiei M, Janjić K, Cvikl B et al. The role of sclerostin and dickkopf-1 in oral tissues - A review from the perspective of the dental disciplines [version 1; peer review: 2 approved] F1000Research 2019, 8:128

https://doi.org/10.12688/f1000research.17801.1

First published: 30 Jan 2019, 8:128 https://doi.org/10.12688/f1000research.17801.1 


\section{Introduction}

Research and development of novel treatment strategies for regenerative dentistry has become crucial to improve oral health due to the growing numbers of dental and maxillofacial problems which require treatment. Therefore, cell-therapy modalities, biologicals, and gene therapy approaches are in development with the aim to provide novel tools for the clinical demands (Dissanayaka et al., 2014; Fretwurst et al., 2018; Itoh et al., 2018; Kaigler et al., 2015; Nevins et al., 2005; Plonka et al., 2017; Taut et al., 2013). This research needs to be guided by an appropriate understanding of the cell biological mechanisms underlying pathological changes and regeneration in the oral tissue, including the periodontium and the dental tissue. Due to the major role of Wnt signaling and the respective regulators in development and healing, research in regenerative medicine and dentistry has evaluated the feasibility of targeting the pathway for therapeutic approaches (Florio et al., 2016; Heiland et al., 2010; Taut et al., 2013; Yu et al., 2018).

The Wnts comprise a family of at least 19 lipid-modified glycoproteins and short-range ligands. Wnts can activate canonical and non-canonical pathways of signaling in the cells (Mohammed et al., 2016; Tang et al., 2009; Yang et al., 2016). The canonical Wnt path involves the interaction of Wnt with frizzled (Frz) and low density lipoprotein receptor-related protein 5/6 (LRP5/6). Thereby $\beta$-catenin accumulation is induced leading to the translocation of $\beta$-catenin into the nucleus where target genes are activated (Mohammed et al., 2016; Tang et al., 2009; Yang et al., 2016) (Figure 1).

Wnt signaling regulates various cellular functions which include cell migration, proliferation, differentiation, apoptosis, and morphogenesis. Given this broad involvement of Wnt signaling it is not surprising that it has a key role in organ development, regeneration and homeostasis of tissues (Logan \& Nusse, 2004; Sarkar \& Sharpe, 2000; Seo et al., 2012). In the maxillofacial region, Wnt signaling modulates morphological patterns in tooth development including teeth number, shape, size, and positioning (Han et al., 2011; Kim et al., 2013; Kratochwil et al., 2002; Liu et al., 2008; Sarkar et al., 2000; Wang et al., 2009;
Zhang et al., 2013). Maturation of dental mesenchyme into odontoblasts and cementoblasts is also modulated by Wnt signaling which highlights the relevance to dentistry (Janjić et al., 2018; Zhang et al., 2013). Given this dominant role of Wnts, Wnt signaling needs to be tightly controlled involving inhibitors.

Sclerostin (SOST) and dickkopf-1 (DKK-1) are the primary inhibitors controlling the Wnt signaling pathways (Figure 1). These inhibitors can directly bind to LRP5/6 and inhibit the activation of LRP5- and LRP6- related signaling. Dkk-1 binds to a larger region on LRP5 and LRP6 extracellular surface and thereby can inhibit binding with other Wnts than SOST. (Ahn et al., 2011; Bourhis et al., 2010; Bourhis et al., 2011; Cheng et al., 2011; Florio et al., 2016; Li et al., 2005; van Bezooijen et al., 2004) Thereby SOST and DKK-1 play critical roles in the formation of hard tissue and associated diseases. SOST and DKK-1 are consequently considered potential therapeutic targets for regenerative approaches (Janjić et al., 2018; Li et al., 2005; Semënov et al., 2005; Taut et al., 2013).

The glycoprotein SOST is mainly secreted by osteocytes, the mechanosensor cells of the bone, and has a major effect on bone and dental tissue (Kuchler et al., 2014; Pflanz et al., 2017; Saag et al., 2017; Taut et al., 2013; Winkler et al., 2003; Yu et al., 2018). In recent years, SOST production in oral tissues has gained more attention and led to in vitro and in vivo studies on the regulation of SOST (Pflanz et al., 2017; Taut et al., 2013; Yu et al., 2018). SOST production in mineralizing periodontal ligament cells is increased; this observation suggests that targeting of SOST might support periodontal regeneration. SOST has also been demonstrated to have a role in the dimension of the periodontal ligament (Kuchler et al., 2014). This further supports the hypothesis of a key role of SOST in oral tissues. DKK-1, another antagonist of Wnt signaling, modulates the dimension of oral tissues, including the periodontium and teeth (Bao et al., 2013; Jäger et al., 2010; MacDonald et al., 2007).

According to the findings of 10 years analysis of publications regarding SOST and DKK-1 in medical fields (Figure 2), it becomes evident that there is a growing set of literature on SOST
A

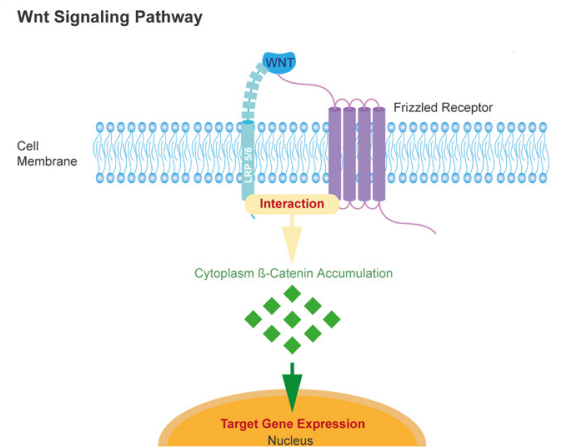

B

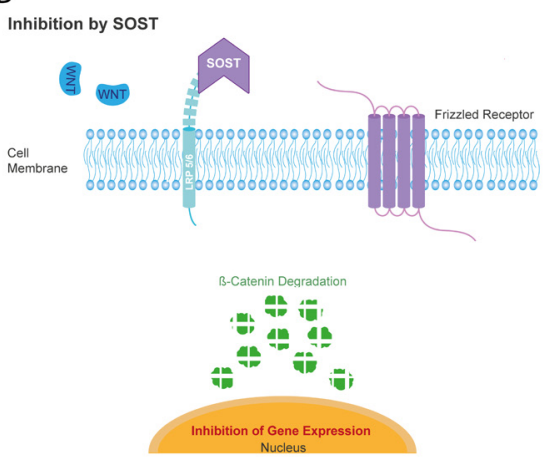

C

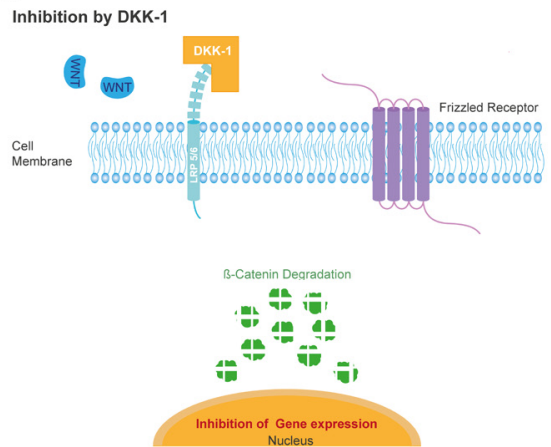

Figure 1. Inhibition of Wnt signaling by sclerostin and dickkopf-1. Scheme of the Wnt signaling pathway (A) which is inhibited by sclerostin (SOST, B) and dickkopf-1 (DKK-1, C). Adopted from (Yorgan \& Schinke, 2014) and modified. 

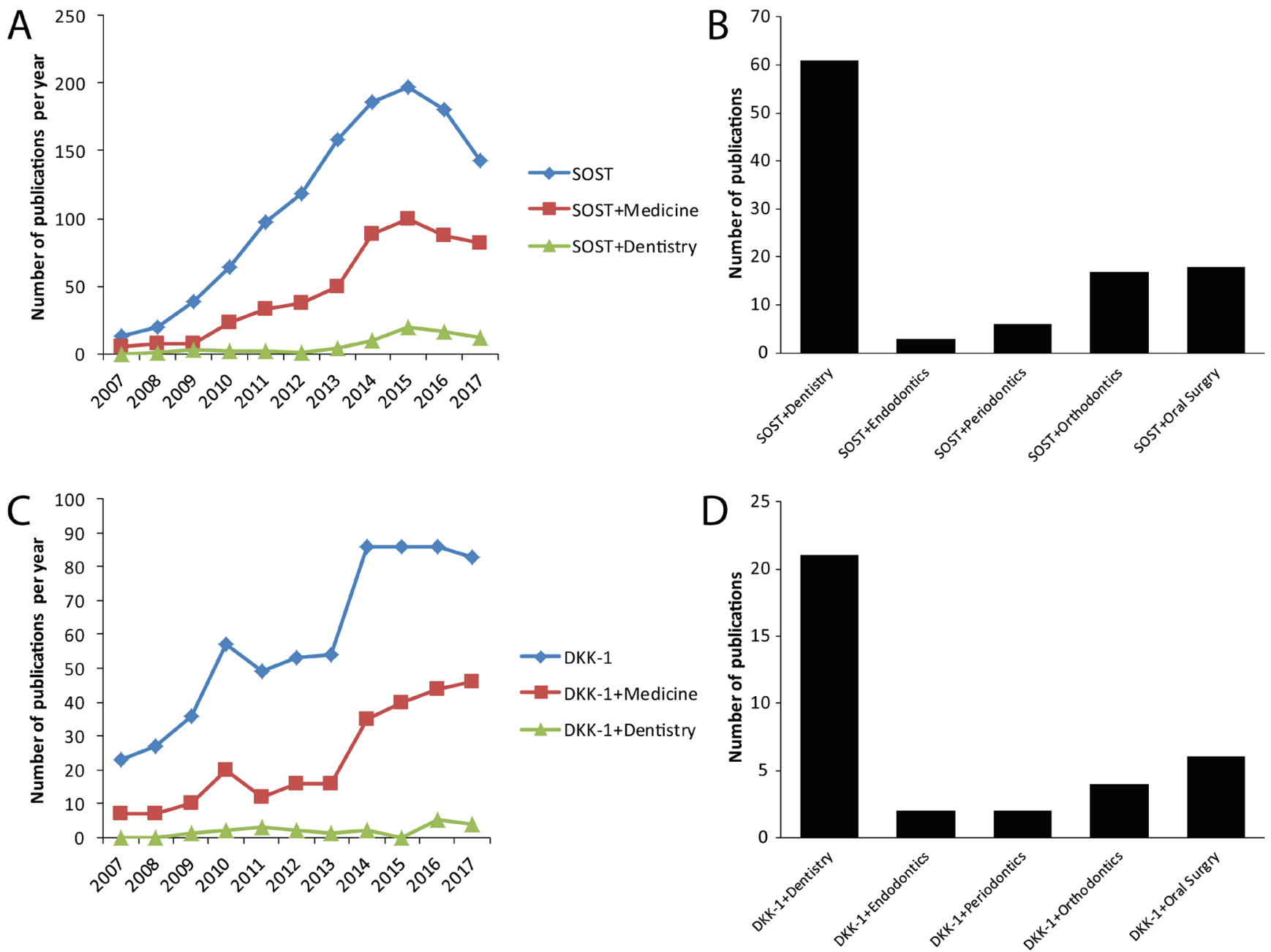

Figure 2. The numbers of publication on sclerostin and dickkopf-1 increased rapidly over the past $\mathbf{1 0}$ years. The number of publications on sclerostin (SOST, A) and dickkopf-1 (DKK-1, C) per year as found in Pubmed.org (Search terms SOST or DKK-1 with and without Medicine or Dentistry). The total number of publications on SOST (B) and DKK-1 (D) in Dentistry and the respective specialties Endodontics, Periodontics, Orthodontics, and Oral Surgery as found in Pubmed.org (Search terms SOST with and without Dentistry, Endodontics, Periodontics, Orthodontics, or Oral Surgery).

and DKK-1. Within dentistry the majority of publications on SOST and DKK-1 is from the field of oral surgery. This review aims to provide a synopsis of the existing knowledge on the Wnt signaling inhibitors SOST and DKK-1 from endodontics, orthodontics, periodontics, and oral surgery perspectives.

\section{Endodontics perspective}

Research and developments in endodontics lead to the continuous improvement of the field, as the introduction of new techniques and biomaterials drive profound progress in endodontic clinical practice. In particular regenerative endodontics is an exciting dental specialty. Treatment protocols of infected root canals in immature teeth were established which allow continued apical closure and root maturation (Chueh \& Huang, 2006; Huang, 2008; Huang et al., 2008). In these regenerative endodontic procedures, after treatment with ethylenediaminetetraacetic acid (EDTA) signaling factors embedded in the dentin matrix such as TGF- $\beta$ are exposed and released into the canal space (Galler et al., 2015). These factors can guide the migration of dental pulp stem cells and support differentiation into odontoblast-like cells, leading to the production of mineralized matrix also termed reparative dentin (Nakashima et al., 1994; Rutherford et al., 1993; Sloan \& Smith, 1999; Tziafas et al., 1998). Interestingly TGF- $\beta$ has the capacity to induce SOST expression (Gruber et al., 2017; Manokawinchoke et al., 2015); therefore, it is possible that dentin conditioning can interfere with the regulation system of Wnt signaling (Gruber et al., 2017; Manokawinchoke et al., 2015).

Clinically applied regenerative protocols, such as revascularization, utilize the regenerative capacity of endogenous stem cells. During treatment, over instrumentation into the periapical tissues causes stem cells to migrate and enter into the canal system via the blood clot. This process leads to the treatment of immature teeth with 
pulp necrosis by replacing dentin, root structures and pulp-dentin complex cells (Diogenes et al., 2016). However, revascularization can be accompanied by intracanal calcification (Song et al., 2017). It is unclear how Wnts and their inhibitors SOST and DKK-1 are involved in this process. Therefore, studies which investigate the regulation of SOST and DKK-1 in pulp cells and tissue under conditions which are present in the early phase of healing are of clear relevance (Janjić et al., 2018).

Results of Zhang et al. indicate that Wnt/B-catenin signaling is required for odontoblastic differentiation and also promotes proliferation of pre-odontoblasts and odontogenesis during root development (Zhang et al., 2013). Based on these findings, the integrity of $\mathrm{Wnt} / \beta$-catenin signaling in odontoblasts is vital for proliferation and differentiation through root formation. Targeted deletion of $\beta$-catenin in odontoblasts leads to incomplete incisors and rootless molars. Furthermore, $\beta$-catenin deficiency disrupts the differentiation of odontoblasts and cementoblasts. (Zhang et al., 2013) Epithelial expression of DKK-1 or epithelium-specific inactivation of $\beta$-catenin causes abnormal tooth development at the early bud stage (Andl et al., 2002; Chen et al., 2009; Han et al., 2011). Mesenchyme-specific inhibition of $\beta$-catenin indicates the critical role of $\mathrm{Wnt} / \beta$-catenin signaling in the potential mesenchymal odontogenic activation throughout early tooth growth (Chen et al., 2009).

After tooth development odontoblasts secrete dentin and the pulp chamber system narrows with age (Arana-Chavez \& Massa, 2004; Foster et al., 2013; Lee et al., 2013; Sakai et al., 2010). While dentin gradually thickens, the pulp chamber space is reduced and a massive bone loss can be observed during aging. (Boskey \& Coleman, 2010; Carvalho \& Lussi, 2017; Gabet \& Bab, 2011) In response to injuries and stress the formation of mineralized tissue by odontoblasts, also termed reparative dentinogenesis, is stimulated. The odontoblasts which are involved in this repair process are clearly responsive to Wnt (Zhao et al., 2018). SOST knockout mice demonstrate dramatically enhanced formation of reparative mineralized bridges and increased mineralization in dental pulp cells compared with wild-type mice (Collignon et al., 2017). These findings are related to an increased SOST expression in wild type cells. Further more these results show that SOST deficiency accelerates reparative dentinogenesis after pulp damage and therefore inhibition of SOST may provide a promising therapeutic strategy to improve the healing of injured pulps (Collignon et al., 2017).

Expression of DKK-1 is up-regulated in a rodent model of induced periapical lesions, suggesting that DKK-1 is involved in the inflammatory processes and bone resorption in periapical lesions (Zhang et al., 2014). Interestingly several potential therapeutic approaches rely on the modulation of Wnt signaling (Ishimoto et al., 2015; Lee et al., 2016; Zhao et al., 2018), including several plant-derived molecules. Baicalein promotes odontoblastic differentiation and angiogenesis of human dental pulp cells. It was suggested that via the inhibition of DKK-1 Baicalein can contribute to regenerative endodontics and dental pulp repair. (Lee et al., 2016).
Given the importance of hypoxia-induced signaling in the early phase of pulp healing we investigated the production of SOST and DKK-1 in dental pulp cells upon treatment with hypoxia or the hypoxia mimetic agent L-mimosine in monolayer, spheroid, and tooth slice cultures. Our results show that the response with regard to SOST and DKK-1 production depends on the culture model.

Taken together, the literature highlights a major role of SOST and DKK-1 in tooth development and as a potential target for regenerative strategies.

\section{Orthodontics perspective}

Orthodontic tooth movement is a result of external force applications to the teeth, an intervention which involves remodeling in dental and surrounding oral tissues, such as periodontal ligament, alveolar bone, and gingiva (Antoun et al., 2017; Krishnan \& Davidovitch, 2006). The applied forces induce displacement of the teeth in the periodontal ligament space, thereby establishing sites where the tissue is compressed and sites were traction establishes (Antoun et al., 2017; Krishnan \& Davidovitch, 2006). Thereby, modeling of the alveolar bone through the processes of bone resorption and bone formation is induced leading to clinical changes in the position of the tooth. (Krishnan \& Davidovitch, 2006; Krishnan \& Davidovitch, 2009; Reitan, 1967)

Mechanical forces can regulate the expression of SOST by osteocytes; for instance the expression of SOST is reduced when loading is increased, and increased when loading is decreased leading to an increase in bone formation or bone loss, respectively (Moustafa et al., 2012; Robling et al., 2008). This feature of SOST indicates that it is a crucial protein in bone formation under mechanical stimulation (Agholme et al., 2011; Mantila Roosa et al., 2011; Robling et al., 2008; ). Given that SOST is produced by osteocytes and cementocytes in alveolar bone and in cellular cementum, respectively, an involvement of SOST in tooth movement is likely (Jäger et al., 2010).

During orthodontic tooth movement, one of the essential processes is remodeling of the periodontal ligament. Periostin is one of the factors which increased in the periodontal ligament during initial stages of orthodontic tooth movement (Wilde et al., 2003), a matricellular protein and collagen-rich tissues which are highly expressed in periosteum under persistent mechanical stress (Horiuchi et al., 1999). Periodontal cells have shown to respond to these mechanical forces with an increase of TGF- $\beta$ which can stimulate SOST (Gruber et al., 2017; Manokawinchoke et al., 2015). The increase in the levels of SOST in the compression side and the decrease in the tension side during tooth movement can be suggestive of an interplay between periostin from Sharpey's fibres and SOST in alveolar bone during orthodontic therapy (Nishiyama et al., 2015).

Cementoblasts are highly differentiated cells from the mesenchymal lineage which generate cementum (Bosshardt, 2005). Diseases that influence bone characteristics often interfere with 
the properties of the cementum, which highlights the similarities of these tissues. Although SOST is expressed in both osteocytes and cementocytes in dental tissues (Jäger et al., 2010), it is still not clear if cementocytes can have similar mechanical stress sensing capacity as osteocytes. However, SOST which is released by osteocytes in the alveolar bone may affect the function of cementoblasts. This process might be modulated upon orthodontic treatment. Research on the role of SOST can also help to understand the impact of therapeutics on the periodontium. Strontium supports differentiation of cementoblasts (Bao et al., 2014) with one possible underlying mechanism being that strontium decreases the production of SOST. Thus, strontium was proposed for regenerative approaches to support cementum production in cases of root resorption. (Bao et al., 2014) However, if SOST or DKK-1 can serve effectively as targets for orthodontic approaches and cementum repair requires further studies.

\section{Periodontics perspective}

Periodontitis is an inflammatory disease of the teeth supporting tissues, has a multifactorial etiology. The inflammation created by specific microorganisms extends deep into the tissues and causes the destruction of the tooth supporting connective tissue and alveolar bone. This progressive process leads to the pathological impairment of collagen fibres, loss of periodontal ligament and alveolar bone recession (Armitage, 2004; Highfield, 2009; Pihlstrom et al., 2005). Evaluation of SOST and DKK-1 in chronic periodontitis patients showed that both of these inhibitors were up-regulated in the periodontal tissues of these subjects (Napimoga et al., 2014).

There are hints from animal studies that inflammation can not only trigger bone resorption, but also decrease bone formation. This anti-anabolic effects seem to be mediated by increased levels of DKK-1 (Heiland et al., 2010). In vitro models of oral soft tissue augmentation suggest that DKK-1 is also increased in oral soft tissue wound healing (Agis et al., 2014). Thus, Wnt inhibitors can play a major role in pathological processes and regeneration in the periodontal tissue. Although periodontitis can be treated in early stages, mostly because of the chronic entity of problem, it is diagnosed in the advanced phase of destruction of the periodontal ligament and the prognosis of maintaining the teeth are poor. Conventional regenerative approaches use biomaterials of natural or synthetic origin as filler for the defect thereby aiding the host to replace lost periodontal tissue and bone. While these interventions can stimulate tissue repair and stop the destruction of the periodontium, methods to archive full regeneration are still the focus of research (Hernández-Monjaraz et al., 2018).

The blocking of Wnt signaling impairs the periodontal ligament and alveolar bone (Lim et al., 2014), while enhancing Wnt signalling by SOST knock out stimulates alveolar bone formation and reduces the width of periodontal ligament (Kuchler et al., 2014). Expression of SOST by cementocytes suggests that these cells may regulate cell activity on the cementum surface (Bao et al., 2013; Lehnen et al., 2012). TGF- $\beta$ can increase the production of SOST in fibroblasts from periodontal ligament and gingiva (Gruber et al., 2017). This mechanism seems to be involved in the impact of mechanical loading on mineralized tissue formation in the periodontal ligament (Manokawinchoke et al., 2015). Deletion of SOST leads to more cellular cementum, in parallel to more dramatically increased alveolar bone deposition (Kuchler et al., 2014). Blocking SOST by application of a SOST-specific antibody enhances healing of alveolar bone in experimental periodontitis (Chen et al., 2015; Liu et al., 2018; Taut et al., 2013). In addition, it was reported that reduced SOST in periostin knockout mice can re-establish periodontal ligament and alveolar bone (Rangiani et al., 2016; Ren et al., 2015). This evidence supports that targeting of SOST is a feasible approach for periodontal therapy.

Dental cementum is a mineralized hard tissue on the surface of root dentin and present either in acellular or cellular form. Defective cementum results in periodontal breakdown, tooth dysfunction, and finally leads to tooth loss. Cementogenesis is a key element in the process of periodontal tissue regeneration (Bosshardt, 2005; Kao \& Fiorellini, 2012). SOST was detected only in cementocytes of cellular cementum in the late stages of cementum development (Lehnen et al., 2012). SOST levels in cementocytes increased in periodontal ligament cultures, following mineralization treatment (Jäger et al., 2010). Interestingly, in periodontal ligament cells Baicalein can promote osteoblastic differentiation involving Wnt/ $\beta$-catenin signaling (Chen et al., 2017). DKK-1 significantly reversed the effects of Baicalein on human periodontal ligament cells (Chen et al., 2017). It is possible that this mechanism can be exploited in regenerative approaches.

The here presented literature supports the significant effects of SOST and DKK-1 in the periodontium system and periodontal diseases. As a result, they could be the main targets in future periodontics regenerative therapies.

\section{Oral surgery perspective}

The alveolar bone supports the tooth in the maxilla and mandible and is characterized by continuous and rapid remodeling in response to mechanical forces (Javed et al., 2010; Pagni et al., 2012). Thereby alveolar bone continuously adapts to functional load. If this mechanical stimuli is lacking the alveolar bone undergoes a resorptive process (Einhorn \& Gerstenfeld, 2015; Pagni et al., 2012; Sodek \& McKee, 2000). Following trauma due to overloading or surgery bone has the capacity to regenerate. While long bone healing occurs by endo-chondral ossification, alveolar bone healing typically occurs without histological cartilage formation (Devlin et al., 1997). The success of oral surgery procedures, such as implants, depends on the proper healing of alveolar bone and strategies which stimulate bone regeneration (Lin et al., 2011). Thus understanding the cell and molecular biological background of bone healing is clearly of clinical relevance.

In bone, SOST is mainly secreted by osteocytes and represents a key modulator of bone homeostasis (Brunkow et al., 2001; van Bezooijen et al., 2004). The importance of SOST in bone formation is illustrated by sclerosteosis, a rare autosomal recessive disorder with a loss-of-function mutation in SOST (Sebastian \& Loots, 2018; Yavropoulou et al., 2014). Further evidence comes from Van Buchem Disease, which is characterized by a noncoding deletion which removes a SOST-specific regulator 
(Sebastian \& Loots, 2018; Yavropoulou et al., 2014). These diseases show bone overgrowth, particularly in the craniofacial bones and the jaw bone (Balemans et al., 2002; Brunkow et al., 2001). There is also a phenotype in oral tissue; partial anodontia, malocclusion, and delayed tooth eruption is seen in subjects with Van Buchem Disease or SOST (Stephen et al., 2001; van Bezooijen et al., 2009). Animal studies on the role of SOST in loss of function or gain function models indicate SOST decreases bone formation and can stimulate bone resorption (Canalis, 2013; Li et al., 2008; O'Brien et al., 2013). SOST knockout mice show a dramatically increased basal mandibular bone and less effect on the coronal and apical part of the alveolar bone (Kuchler et al., 2014).

The response of bone to mechanical loading is highly important in implantology. Since SOST is a key player in the regulation of bone formation in the response to mechanical loading it is important to understand its role in the alveolar bone. Upon loading, osteocytes reduce the expression of SOST permitting Wnts to bind their receptors. (Burgers \& Williams, 2013; Galli et al., 2010; Zhao et al., 2013). Interestingly, SOST expression is up-regulated around implants without primary stability (Shu et al., 2017). Thus, it is very likely that SOST regulates the adaptation of bone around dental implants to the mechanical forces of loading. Application of SOST specific antibodies has been shown to stimulate bone formation around dental implants (Yu et al., 2018).

DKK-1 can decrease $\mathrm{Wnt} / \beta$ catenin signalling and reduced the production of type II collagen in chondrocytes under mechanical loading (Niu et al., 2016). Interestingly, DKK-1 has been found to play a distinct role in inflammation-induced bone loss (Heiland et al., 2010). However, when evaluating genetic markers for peri-implantitis clinically, no direct relation of DKK-1 and peri-implantitis is seen (Hall et al., 2011). Thus, further research is required to understand the role of DKK-1 in the alveolar bone.

From a clinical standpoint, osteoporosis is a risk factor in implantology. Inspired by the fact that inhibition of SOST can effectively improve bone formation in osteoporotic patients strategies which harness this capacity to improve bone formation around implants have been evaluated. (Canalis, 2013; Costa \& Bilezikian, 2012; Recker et al., 2015; Shu et al., 2017). Implant osseointegration is superior in the SOST knockout mice suggesting that SOST is a promising target to enhance implant osseointegration in osteoporosis. (Shu et al., 2017) Also application of antibodies specific for SOST can improve bone formation around implants (Yu et al., 2018).

Taken together these data show the relevance of the Wnt signalling inhibitors of SOST and DKK-1 for implantology and bone augmentation, as well as for tumor development and cancer therapy. Future studies will show how effective targeting of SOST and DKK-1 can be applied to stimulate regeneration and for tumor therapy.

\section{Conclusion}

The here presented review highlights the relevance of Wnt signaling, the inhibitors SOST and DKK-1, and its key role in oral tissue homeostasis throughout life (Florio et al., 2016; Heiland et al., 2010; Witcher et al., 2018). Major sources of Wnt inhibitors are the mechanosensors of the bone, the osteocytes (Moustafa et al., 2012; Odagaki et al., 2018; Robling et al., 2008). Cells from oral tissue including cementocytes can modulate Wnt signaling by these inhibitors and mice deficient of SOST or DKK-1 have highlighted the important role in the oral tissue (Jäger et al., 2010; Lehnen et al., 2012). Based on this knowledge concepts to antagonize inhibitors Wnt signaling have been developed to support oral tissue regeneration (Taut et al., 2013; Yu et al., 2018). The future will reveal the capacity of these strategies which target these Wnt signaling inhibitors for regenerative therapy in dentistry. Given the interplay of SOST and DKK-1, a bidirectional approach which targets both SOST and DKK-1 locally has high potential (Florio et al., 2016).

\section{Data availability}

No data is associated with this article.

\section{Grant information}

We thank the European Society of Endodontology (ESE) for financial support of our research [ESE research grant 2015]. The authors deny any conflict of interest.

The funders had no role in study design, data collection and analysis, decision to publish, or preparation of the manuscript.
Agholme $\mathrm{F}$, Isaksson $\mathrm{H}$, Li X, et al: Anti-sclerostin antibody and mechanical loading appear to influence metaphyseal bone independently in rats. Acta Orthop. 2011; 82(5): 628-632.

PubMed Abstract | Publisher Full Text | Free Full Text

Agis $\mathrm{H}$, Collins $\mathrm{A}$, Taut AD, et al.: Cell population kinetics of collagen scaffolds in ex vivo oral wound repair. PLOS One. 2014; 9(11): e112680.

PubMed Abstract | Publisher Full Text | Free Full Text

Ahn VE, Chu ML, Choi HJ, et al:: Structural basis of Wnt signaling inhibition by

Dickkopf binding to LRP5/6. Dev Cell. 2011; 21(5): 862-873.

PubMed Abstract | Publisher Full Text | Free Full Text
Andl T, Reddy ST, Gaddapara T, et al: WNT signals are required for the initiation of hair follicle development. Dev Cell. 2002; 2(5): 643-653. PubMed Abstract | Publisher Full Text

Antoun JS, Mei L, Gibbs K, et al:: Effect of orthodontic treatment on the periodontal tissues. Periodontol 2000. 2017; 74(1): 140-157.

PubMed Abstract | Publisher Full Text

Arana-Chavez VE, Massa LF: Odontoblasts: the cells forming and maintaining dentine. Int J Biochem Cell Biol. 2004; 36(8): 1367-1373.

PubMed Abstract | Publisher Full Text

Armitage GC: Periodontal diagnoses and classification of periodontal 
diseases. Periodontol 2000. 2004; 34(1): 9-21.

PubMed Abstract | Publisher Full Text

Balemans W, Patel N, Ebeling M, et al:: Identification of a $\mathbf{5 2} \mathbf{~ k b}$ deletion downstream of the SOST gene in patients with van Buchem disease. $J$ Med Genet. 2002; 39(2): 91-97.

PubMed Abstract | Publisher Full Text | Free Full Text

Bao X, Liu Y, Han G, et al:: The effect on proliferation and differentiation of cementoblast by using sclerostin as inhibitor. Int J Mol Sci. 2013; 14(10): 21140-21152.

PubMed Abstract | Publisher Full Text | Free Full Text

Bao X, Liu X, Zhang Y, et al:: Strontium promotes cementoblasts differentiation through inhibiting sclerostin expression in vitro. Biomed Res Int. 2014; 2014: 487535 .

PubMed Abstract | Publisher Full Text | Free Full Text

Boskey AL, Coleman R: Aging and bone. J Dent Res. 2010; 89(12): 1333-1348. PubMed Abstract | Publisher Full Text | Free Full Text

Bosshardt DD: Are cementoblasts a subpopulation of osteoblasts or a unique phenotype? J Dent Res. 2005; 84(5): 390-406.

PubMed Abstract | Publisher Full Text

Bourhis E, Tam C, Franke Y, et al.: Reconstitution of a frizzled8.Wnt3a.LRP6 signaling complex reveals multiple Wnt and Dkk1 binding sites on LRP6. J Biol Chem. 2010; 285(12): 9172-9179.

PubMed Abstract | Publisher Full Text | Free Full Text

Bourhis E, Wang W, Tam C, et al: Wnt antagonists bind through a short peptide to the first $\beta$-propeller domain of LRP5/6. Structure. 2011; 19(10): 1433-1442. PubMed Abstract | Publisher Full Text

Brunkow ME, Gardner JC, Van Ness J, et al.: Bone dysplasia sclerosteosis results from loss of the SOST gene product, a novel cystine knot-containing

protein. Am J Hum Genet. 2001; 68(3): 577-589.

PubMed Abstract | Publisher Full Text | Free Full Text

Burgers TA, Williams BO: Regulation of Wnt/ $\beta$-catenin signaling within and from osteocytes. Bone. 2013; 54(2): 244-249.

PubMed Abstract | Publisher Full Text | Free Full Text

Canalis $\mathrm{E}$ : Wnt signalling in osteoporosis: mechanisms and novel therapeutic approaches. Nat Rev Endocrinol. 2013; 9(10): 575-583.

PubMed Abstract | Publisher Full Text

Carvalho TS, Lussi A: Age-related morphological, histological and functiona changes in teeth. J Oral Rehabil. 2017; 44(4): 291-298.

PubMed Abstract | Publisher Full Text

Chen $\mathrm{H}, \mathrm{Xu} \mathrm{X,} \mathrm{Liu} \mathrm{M,} \mathrm{et} \mathrm{al.:} \mathrm{Sclerostin} \mathrm{antibody} \mathrm{treatment} \mathrm{causes} \mathrm{greater}$ alveolar crest height and bone mass in an ovariectomized rat model of localized periodontitis. Bone. 2015; 76: 141-148.

PubMed Abstract | Publisher Full Text

Chen J, Lan Y, Baek JA, et al:: Wnt/beta-catenin signaling plays an essential role in activation of odontogenic mesenchyme during early tooth development. Dev Biol. 2009; 334(1): 174-185

PubMed Abstract | Publisher Full Text | Free Full Text

Chen LJ, Hu BB, Shi XL, et al: Baicalein enhances the osteogenic

differentiation of human periodontal ligament cells by activating the Wnt/ $\mathrm{B}$ -

catenin signaling pathway. Arch Oral Biol. 2017; 78: 100-108.

PubMed Abstract | Publisher Full Text

Cheng Z, Biechele T, Wei Z, et al:: Crystal structures of the extracellular domain of LRP6 and its complex with DKK1. Nat Struct Mol Biol. 2011: 18(11): 1204-1210. PubMed Abstract | Publisher Full Text | Free Full Text

Chueh LH, Huang GT: Immature teeth with periradicular periodontitis or abscess undergoing apexogenesis: a paradigm shift. J Endod. 2006; 32(12): 1205-1213.

PubMed Abstract | Publisher Full Text

Collignon AM, Amri N, Lesieur J, et al:: Sclerostin Deficiency Promotes

Reparative Dentinogenesis. J Dent Res. 2017; 96(7): 815-821.

PubMed Abstract | Publisher Full Text

Costa AG, Bilezikian JP: Sclerostin: therapeutic horizons based upon its actions. Curr Osteoporos Rep. 2012; 10(1): 64-72.

PubMed Abstract | Publisher Full Text

Devlin H, Hoyland J, Newall JF, et al:: Trabecular bone formation in the healing of the rodent molar tooth extraction socket. J Bone Miner Res. 1997; 12(12): 2061-2067.

PubMed Abstract | Publisher Full Tex

Diogenes A, Ruparel NB, Shiloah Y, et al.: Regenerative endodontics: A way forward. J Am Dent Assoc. 2016; 147(5): 372-380.

PubMed Abstract | Publisher Full Text

Dissanayaka WL, Zhu L, Hargreaves KM, et al:: Scaffold-free Prevascularized

Microtissue Spheroids for Pulp Regeneration. J Dent Res. 2014; 93(12):

1296-1303.

PubMed Abstract | Publisher Full Text | Free Full Text

Einhorn TA, Gerstenfeld LC: Fracture healing: mechanisms and interventions.

Nat Rev Rheumatol. 2015; 11(1): 45-54.

PubMed Abstract | Publisher Full Text | Free Full Text

Florio M, Gunasekaran K, Stolina M, et al:: A bispecific antibody targeting

sclerostin and DKK-1 promotes bone mass accrual and fracture repair. Nat

Commun. 2016; 7: 11505.

PubMed Abstract | Publisher Full Text | Free Full Text

Foster BL, Nagatomo KJ, Tso HW, et al:: Tooth root dentin mineralization defects in a mouse model of hypophosphatasia. J Bone Miner Res. 2013; 28(2): 271-282.

PubMed Abstract | Publisher Full Text | Free Full Text

Fretwurst T, Larsson L, Yu SH, et al.: Periodontal Tissue Bioengineering: Is the Future Now? Compend Contin Educ Dent. 2018; 39(4): 218-223; quiz 224 PubMed Abstract

Gabet $Y, B a b$ I: Microarchitectural changes in the aging skeleton. Curr Osteoporos Rep. 2011; 9(4): 177-183.

PubMed Abstract | Publisher Full Text

Galler KM, Buchalla W, Hiller KA, et al:: Influence of root canal disinfectants on growth factor release from dentin. J Endod. 2015; 41(3): 363-368.

PubMed Abstract | Publisher Full Text

Galli C, Passeri G, Macaluso GM: Osteocytes and WNT: the mechanical control of bone formation. J Dent Res. 2010; 89(4): 331-343.

PubMed Abstract | Publisher Full Text

Gruber M, Gruber R, Agis H: Transforming growth factor- $\beta 1$ increases sclerostin in fibroblasts of the periodontal ligament and the gingiva - Matters. Matters Archive. 2017.

Reference Source

Hall J, Britse AO, Jemt T, et al:: A controlled clinical exploratory study on genetic markers for peri-implantitis. Eur J Oral Implantol. 2011; 4(4): 371-382. PubMed Abstract

Han XL, Liu M, Voisey A, et al.: Post-natal effect of overexpressed DKK1 on mandibular molar formation. J Dent Res. 2011; 90(11): 1312-1317.

PubMed Abstract | Publisher Full Text | Free Full Text

Heiland GR, Zwerina K, Baum W, et al.: Neutralisation of Dkk-1 protects from systemic bone loss during inflammation and reduces sclerostin expression. Ann Rheum Dis. 2010; 69(12): 2152-2159.

PubMed Abstract | Publisher Full Text

Hernández-Monjaraz B, Santiago-Osorio E, Monroy-García A, et al.: Mesenchymal Stem Cells of Dental Origin for Inducing Tissue Regeneration in Periodontitis: A Mini-Review. Int J Mol Sci. 2018; 19(4): pii: E944.

PubMed Abstract | Publisher Full Text | Free Full Text

Highfield J: Diagnosis and classification of periodontal disease. Aust Dent $\mathrm{J}$. 2009; 54 Suppl 1: S11-26.

PubMed Abstract | Publisher Full Text

Horiuchi K, Amizuka N, Takeshita S, et al:: Identification and characterization of a novel protein, periostin, with restricted expression to periosteum and periodontal ligament and increased expression by transforming growth factor beta. J Bone Miner Res. 1999; 14(7): 1239-1249.

PubMed Abstract | Publisher Full Text

Huang GT: A paradigm shift in endodontic management of immature teeth: conservation of stem cells for regeneration. J Dent. 2008; 36(6): 379-386.

PubMed Abstract | Publisher Full Text

Huang GT, Sonoyama W, Liu Y, et al:: The hidden treasure in apical papilla: the potential role in pulp/dentin regeneration and bioroot engineering. $J$ Endod. 2008; 34(6): 645-651.

PubMed Abstract | Publisher Full Text | Free Full Text

Ishimoto K, Hayano S, Yanagita T, et al:: Topical application of lithium chloride on the pulp induces dentin regeneration. PLOS One. 2015; 10(3): e0121938. PubMed Abstract | Publisher Full Text | Free Full Text

Itoh Y, Sasaki JI, Hashimoto M, et al.: Pulp Regeneration by 3-dimensiona Dental Pulp Stem Cell Constructs. J Dent Res. 2018; 97(10): 1137-1143. PubMed Abstract | Publisher Full Text

Jäger A, Götz W, Lossdörfer S, et al.: Localization of SOST/sclerostin in cementocytes in vivo and in mineralizing periodontal ligament cells in vitro.

J Periodontal Res. 2010; 45(2): 246-254.

PubMed Abstract | Publisher Full Text

Janjić K, Cvikl B, Kurzmann C, et al.: Do hypoxia and L-mimosine modulate sclerostin and dickkopf-1 production in human dental pulp-derived cells? Insights from monolayer, spheroid and tooth slice cultures. BMC Oral Health. 2018; 18(1): 36 .

PubMed Abstract | Publisher Full Text | Free Full Text

Javed A, Chen H, Ghori FY: Genetic and transcriptional control of bone formation. Oral Maxillofac Surg Clin North Am. 2010; 22(3): 283-93, v.

PubMed Abstract | Publisher Full Text | Free Full Text

Kaigler D, Avila-Ortiz G, Travan S, et al:: Bone Engineering of Maxillary Sinus Bone Deficiencies Using Enriched CD90+ Stem Cell Therapy: A Randomized Clinical Trial. J Bone Miner Res. 2015; 30(7): 1206-1216.

PubMed Abstract | Publisher Full Text

Kao DW, Fiorellini JP: Regenerative periodontal therapy. Front Oral Biol. 2012; 15: $149-159$.

PubMed Abstract | Publisher Full Text

$\mathrm{Kim} \mathrm{TH}, \mathrm{Bae} \mathrm{CH}$, Lee JC, et al:: $\beta$-catenin is required in odontoblasts for tooth root formation. J Dent Res. 2013; 92(3): 215-221.

PubMed Abstract | Publisher Full Text

Kratochwil K, Galceran J, Tontsch S, et al.: FGF4, a direct target of LEF1 and Wnt signaling, can rescue the arrest of tooth organogenesis in Lef1 ${ }^{-1}$ mice. Genes Dev. 2002; 16(24): 3173-3185

PubMed Abstract | Publisher Full Text | Free Full Text

Krishnan V, Davidovitch Z: Cellular, molecular, and tissue-level reactions to orthodontic force. Am J Orthod Dentofacial Orthop. 2006; 129(4): 469.e1-32. PubMed Abstract | Publisher Full Tex 
Krishnan V, Davidovitch Z: On a path to unfolding the biological mechanisms of orthodontic tooth movement. J Dent Res. 2009; 88(7): 597-608. PubMed Abstract | Publisher Full Text

Kuchler U, Schwarze UY, Dobsak T, et al.: Dental and periodontal phenotype in sclerostin knockout mice. Int J Oral Sci. 2014; 6(2): 70-76.

PubMed Abstract | Publisher Full Text | Free Full Text

Lee SI, Kim SY, Park KR, et al.: Baicalein Promotes Angiogenesis and Odontoblastic Differentiation via the BMP and Wnt Pathways in Human Dental Pulp Cells. Am J Chin Med. 2016; 44(7): 1457-1472.

PubMed Abstract | Publisher Full Text

Lee $\mathrm{YH}$, Kim GE, Cho HJ, et al.: Aging of in vitro pulp illustrates change of inflammation and dentinogenesis. J Endod. 2013; 39(3): 340-345.

PubMed Abstract | Publisher Full Text

Lehnen SD, Götz W, Baxmann M, et al.: Immunohistochemical evidence for sclerostin during cementogenesis in mice. Ann Anat. 2012; 194(5): 415-421. PubMed Abstract | Publisher Full Tex

Li X, Ominsky MS, Niu QT, et al:: Targeted deletion of the sclerostin gene in mice results in increased bone formation and bone strength. $J$ Bone Miner Res. 2008; 23(6): 860-869.

PubMed Abstract | Publisher Full Text

Li X, Zhang Y, Kang H, et al:: Sclerostin binds to LRP5/6 and antagonizes canonical Wnt signaling. J Biol Chem. 2005; 280(20): 19883-19887.

PubMed Abstract | Publisher Full Text

Lim WH, Liu B, Cheng D, et al:: Wnt signaling regulates homeostasis of the periodontal ligament. J Periodontal Res. 2014; 49(6): 751-759.

PubMed Abstract | Publisher Full Text | Free Full Text

Lin Z, Rios HF, Volk SL, et al.: Gene expression dynamics during bone healing and osseointegration. J Periodontol. 2011; 82(7): 1007-1017.

PubMed Abstract | Publisher Full Text | Free Full Text

Liu F, Chu EY, Watt B, et al.: Wnt/beta-catenin signaling directs multiple stages of tooth morphogenesis. Dev Biol. 2008; 313(1): 210-224.

PubMed Abstract | Publisher Full Text | Free Full Text

Liu M, Kurimoto $P$, Zhang J, et al:: Sclerostin and DKK1 Inhibition Preserves and Augments Alveolar Bone Volume and Architecture in Rats with Alveolar Bone Loss. J Dent Res. 2018; 97(9): 1031-1038.

PubMed Abstract | Publisher Full Text

Logan CY, Nusse R: The Wnt signaling pathway in development and disease. Annu Rev Cell Dev Biol. 2004; 20: 781-810.

PubMed Abstract | Publisher Full Text

MacDonald BT, Joiner DM, Oyserman SM, et al:: Bone mass is inversely

proportional to Dkk1 levels in mice. Bone. 2007; 41(3): 331-339.

PubMed Abstract | Publisher Full Text | Free Full Text

Manokawinchoke J, Limjeerajarus N, Limjeerajarus C, et al: Mechanical Forceinduced TGFB1 Increases Expression of SOST/POSTN by hPDL Cells. J Dent

Res. 2015; 94(7): 983-989.

PubMed Abstract | Publisher Full Text

Mantila Roosa SM, Liu Y, Turner CH: Gene expression patterns in bone

following mechanical loading. J Bone Miner Res. 2011; 26(1): 100-112.

PubMed Abstract | Publisher Full Text | Free Full Text

Mohammed MK, Shao C, Wang J, et al.: Wnt/ß-catenin signaling plays an ever-expanding role in stem cell self-renewal, tumorigenesis and cancer chemoresistance. Genes Dis. 2016; 3(1): 11-40.

PubMed Abstract | Publisher Full Text | Free Full Text

Moustafa A, Sugiyama T, Prasad J, et al.: Mechanical loading-related changes in osteocyte sclerostin expression in mice are more closely associated with the subsequent osteogenic response than the peak strains engendered. Osteoporos Int 2012: 23(4): 1225-1234.

PubMed Abstract | Publisher Full Text | Free Full Text

Nakashima M, Nagasawa $\mathrm{H}$, Yamada $\mathrm{Y}$, et al.: Regulatory role of transforming growth factor-beta, bone morphogenetic protein-2, and protein-4 on gene expression of extracellular matrix proteins and differentiation of dental pulp cells. Dev Biol. 1994; 162(1): 18-28.

PubMed Abstract | Publisher Full Text

Napimoga MH, Nametala C, da Silva FL, et al:: Involvement of the Wnt- $\beta$-catenin signalling antagonists, sclerostin and dickkopf-related protein 1, in chronic periodontitis. J Clin Periodontol. 2014; 41(6): 550-557.

PubMed Abstract | Publisher Full Text

Nevins M, Giannobile WV, McGuire MK, et al:: Platelet-derived growth facto stimulates bone fill and rate of attachment level gain: results of a large multicenter randomized controlled trial. J Periodontol. 2005; 76(12): 2205-2215. PubMed Abstract | Publisher Full Text

Nishiyama Y, Matsumoto T, Lee JW, et al.: Changes in the spatial distribution of sclerostin in the osteocytic lacuno-canalicular system in alveolar bone due to orthodontic forces, as detected on multimodal confocal fluorescence imaging analyses. Arch Oral Biol. 2015; 60(1): 45-54.

PubMed Abstract | Publisher Full Text

Niu Q, Li F, Zhang L, et al.: Role of the Wnt/B-catenin signaling pathway in the response of chondrocytes to mechanical loading. Int J Mol Med. 2016; 37(3): $755-762$

PubMed Abstract | Publisher Full Text

O'Brien CA, Nakashima T, Takayanagi H: Osteocyte control of osteoclastogenesis. Bone. 2013; 54(2): 258-263.

PubMed Abstract | Publisher Full Text | Free Full Text
Odagaki N, Ishihara Y, Wang Z, et al.: Role of Osteocyte-PDL Crosstalk in Tooth Movement via SOST/Sclerostin. J Dent Res. 2018; 97(12): 1374-1382.

PubMed Abstract | Publisher Full Text

Pagni G, Pellegrini G, Giannobile WV, et al:: Postextraction alveolar ridge preservation: biological basis and treatments. Int J Dent. 2012; 2012: 151030. PubMed Abstract | Publisher Full Text | Free Full Text

Pflanz D, Birkhold Al, Albiol L, et al:: Sost deficiency led to a greater cortical bone formation response to mechanical loading and altered gene expression. Sci Rep. 2017; 7(1): 9435

PubMed Abstract | Publisher Full Text | Free Full Text

Pihlstrom BL, Michalowicz BS, Johnson NW: Periodontal diseases. Lancet. 2005 366(9499): 1809-1820

PubMed Abstract | Publisher Full Text

Plonka AB, Khorsand B, Yu N, et al:: Effect of sustained PDGF nonviral gene delivery on repair of tooth-supporting bone defects. Gene Ther. 2017; 24(1): 31-39.

PubMed Abstract | Publisher Full Text | Free Full Text

Rangiani A, Jing Y, Ren Y, et al:: Critical roles of periostin in the process of orthodontic tooth movement. Eur J Orthod. 2016; 38(4): 373-378.

PubMed Abstract | Publisher Full Text | Free Full Text

Recker RR, Benson CT, Matsumoto T, et al.: A randomized, double-blind phase 2 clinical trial of blosozumab, a sclerostin antibody, in postmenopausal women with low bone mineral density. J Bone Miner Res. 2015; 30(2): 216-224.

PubMed Abstract | Publisher Full Text

Reitan K: Clinical and histologic observations on tooth movement during and after orthodontic treatment. Am J Orthod. 1967; 53(10): 721-745.

PubMed Abstract | Publisher Full Text

Ren $\mathrm{Y}$, Han X, Ho SP, et al:: Removal of SOST or blocking its product sclerostin rescues defects in the periodontitis mouse model. FASEB J. 2015; 29(7): 2702-2711.

PubMed Abstract | Publisher Full Text | Free Full Text

Robling AG, Niziolek PJ, Baldridge LA, et al:: Mechanical stimulation of bone in vivo reduces osteocyte expression of Sost/sclerostin. J Biol Chem. 2008; 283(9): 5866-5875.

PubMed Abstract | Publisher Full Text

Rutherford RB, Wahle J, Tucker M, et al: Induction of reparative dentine formation in monkeys by recombinant human osteogenic protein-1. Arch Oral Biol. 1993; 38(7): 571-576.

PubMed Abstract | Publisher Full Text

Saag KG, Petersen J, Brandi ML, et al.: Romosozumab or Alendronate for Fracture Prevention in Women with Osteoporosis. N Engl J Med. 2017; 377(15): 1417-1427.

PubMed Abstract | Publisher Full Text

Sakai VT, Zhang Z, Dong Z, et al: SHED differentiate into functional odontoblasts and endothelium. J Dent Res. 2010; 89(8): 791-796.

PubMed Abstract | Publisher Full Text

Sarkar L, Cobourne M, Naylor S, et al.: Wnt/Shh interactions regulate ectoderma boundary formation during mammalian tooth development. Proc Natl Acad Sci U S A. 2000; 97(9): 4520-4524.

PubMed Abstract | Publisher Full Text | Free Full Text

Sarkar L, Sharpe PT: Inhibition of Wnt signaling by exogenous Mfrzb1 protein affects molar tooth size. J Dent Res. 2000; 79(4): 920-925.

PubMed Abstract | Publisher Full Text

Sebastian A, Loots GG: Genetics of Sost/SOST in sclerosteosis and van Buchem disease animal models. Metabolism. 2018; 80: 38-47. PubMed Abstract | Publisher Full Text

Semënov M, Tamai K, He X: SOST is a ligand for LRP5/LRP6 and a Wnt signaling inhibitor. J Biol Chem. 2005; 280(29): 26770-26775.

PubMed Abstract | Publisher Full Tex

Seo MS, Hwang KG, Kim H, et al:: Analysis of gene expression during odontogenic differentiation of cultured human dental pulp cells. Restor Dent Endod. 2012; 37(3): 142-148.

PubMed Abstract | Publisher Full Text | Free Full Text

Shu R, Ai D, Bai D, et al:: The effects of SOST on implant osseointegration in ovariectomy osteoporotic mice. Arch Oral Biol. 2017; 74: 82-91.

PubMed Abstract | Publisher Full Tex

Sloan AJ, Smith AJ: Stimulation of the dentine-pulp complex of rat incisor teeth by transforming growth factor-beta isoforms 1-3 in vitro. Arch Oral Biol. 1999; 44(2): 149-156

PubMed Abstract | Publisher Full Text

Sodek J, McKee MD: Molecular and cellular biology of alveolar bone.

Periodontol 2000. 2000; 24(1): 99-126.

PubMed Abstract | Publisher Full Tex

Song M, Cao Y, Shin SJ, et al: Revascularization-associated Intracanal

Calcification: Assessment of Prevalence and Contributing Factors. $J$ Endod.

2017; 43(12): 2025-2033

PubMed Abstract | Publisher Full Tex

Stephen LX, Hamersma H, Gardner J, et al:: Dental and oral manifestations of sclerosteosis. Int Dent J. 2001; 51(4): 287-290.

PubMed Abstract | Publisher Full Text

Tang N, Song WX, Luo J, et al:: BMP-9-induced osteogenic differentiation of 
mesenchymal progenitors requires functional canonical Wnt/beta-catenin signalling. J Cell Mol Med. 2009; 13(8B): 2448-2464. PubMed Abstract | Publisher Full Text | Free Full Text

Taut $A D$, Jin $Q$, Chung JH, et al:: Sclerostin antibody stimulates bone regeneration after experimental periodontitis. J Bone Miner Res. 2013; 28(11): 2347-2356

PubMed Abstract | Publisher Full Text

Tziafas D, Alvanou A, Papadimitriou S, et al.: Effects of recombinant basic fibroblast growth factor, insulin-like growth factor-II and transforming growth factor-beta 1 on dog dental pulp cells in vivo. Arch Oral Biol. 1998; 43(6): 431-444. PubMed Abstract | Publisher Full Text

van Bezooijen RL, Bronckers AL, Gortzak RA, et al:: Sclerostin in mineralized matrices and van Buchem disease. J Dent Res. 2009; 88(6): 569-574.

PubMed Abstract | Publisher Full Text

van Bezooijen RL, Roelen BA, Visser A, et al:: Sclerostin is an osteocyteexpressed negative regulator of bone formation, but not a classical BMP antagonist. J Exp Med. 2004; 199(6): 805-814.

PubMed Abstract | Publisher Full Text | Free Full Text

Wang XP, O'Connell DJ, Lund JJ, et al.: Apc inhibition of Wnt signaling regulates supernumerary tooth formation during embryogenesis and throughout

adulthood. Development. 2009; 136(11): 1939-1949.

PubMed Abstract | Publisher Full Text | Free Full Text

Wilde J, Yokozeki M, Terai K, et al:: The divergent expression of periostin mRNA in the periodontal ligament during experimental tooth movement. Cell Tissue

Res. 2003; 312(3): 345-351.

PubMed Abstract | Publisher Full Text

Winkler DG, Sutherland MK, Geoghegan JC, et al:: Osteocyte control of bone formation via sclerostin, a novel BMP antagonist. EMBO J. 2003; 22(23):

6267-6276.

PubMed Abstract | Publisher Full Text | Free Full Text

Witcher PC, Miner SE, Horan DJ, et al:: Sclerostin neutralization unleashes the osteoanabolic effects of Dkk1 inhibition. JCl Insight. 2018; 3(11): pii: 98673. PubMed Abstract | Publisher Full Text | Free Full Text

Yang $\mathrm{K}$, Wang $\mathrm{X}$, Zhang $\mathrm{H}$, et al.: The evolving roles of canonical WNT signaling in stem cells and tumorigenesis: implications in targeted cancer therapies.

Lab Invest. 2016; 96(2): 116-136.

PubMed Abstract | Publisher Full Text | Free Full Text

Yavropoulou MP, Xygonakis C, Lolou M, et al.: The sclerostin story: from human genetics to the development of novel anabolic treatment for osteoporosis.

Hormones (Athens). 2014; 13(4): 323-337.

PubMed Abstract | Publisher Full Text

Yorgan TA, Schinke T: Relevance of Wnt signaling for osteoanabolic therapy. Mol Cell Ther. 2014; 2: 22.

PubMed Abstract | Publisher Full Text | Free Full Text

Yu SH, Hao J, Fretwurst T, et al:: Sclerostin-Neutralizing Antibody Enhances Bone Regeneration Around Oral Implants. Tissue Eng Part A. 2018; 24(21-22): 1672-1679.

PubMed Abstract | Publisher Full Text

Zhang R, Huang S, Wang L, et al.: Histochemical localization of Dickkopf-1 in induced rat periapical lesions. J Endod. 2014; 40(9): 1394-1399.

PubMed Abstract | Publisher Full Text

Zhang R, Yang G, Wu X, et al.: Disruption of Wnt/ק-catenin signaling in odontoblasts and cementoblasts arrests tooth root development in postnata mouse teeth. Int J Biol Sci. 2013; 9(3): 228-236.

PubMed Abstract | Publisher Full Text | Free Full Text

Zhao L, Shim JW, Dodge TR, et al:: Inactivation of Lrp5 in osteocytes reduces young's modulus and responsiveness to the mechanical loading. Bone. 2013 54(1): 35-43.

PubMed Abstract | Publisher Full Text | Free Full Text

Zhao Y, Yuan X, Liu B, et al:: Wnt-Responsive Odontoblasts Secrete New Dentin after Superficial Tooth Injury. J Dent Res. 2018; 97(9): 1047-1054

PubMed Abstract | Publisher Full Text | Free Full Text 


\section{Open Peer Review}

\section{Current Peer Review Status:}

\section{Version 1}

Reviewer Report 15 April 2019

https://doi.org/10.5256/f1000research.19462.r46090

(C) 2019 Jin Q. This is an open access peer review report distributed under the terms of the Creative Commons Attribution License, which permits unrestricted use, distribution, and reproduction in any medium, provided the original work is properly cited.

\section{Qiming Jin}

Department of Cariology, Restorative Sciences, and Endodontics, School of Dentistry, University of Michigan, Ann Arbor, MI, USA

This manuscript is a review paper on sclerostin and dickkopf- 1 impacts on dentistry. The authors made good publication search work, and reviewed the expressions and biological functions of sclerostin and DKK-1 in each parts of tooth and surrounding tissues. Furthermore, the authors explored the correlation between SOST and DKK-1 and various pathologies. More importantly, the treatment pathways to target SOST and DKK-1 were discussed profoundly. The only flaw is the lack of SOST and DKK-1 in enamel formation, which does not affect the merits of this paper.

Is the topic of the review discussed comprehensively in the context of the current literature?

Yes

Are all factual statements correct and adequately supported by citations?

Yes

Is the review written in accessible language?

Yes

Are the conclusions drawn appropriate in the context of the current research literature? Yes

Competing Interests: No competing interests were disclosed.

Reviewer Expertise: periodontal regeneration and dental implant researches

I confirm that I have read this submission and believe that I have an appropriate level of expertise to confirm that it is of an acceptable scientific standard. 
Reviewer Report 04 February 2019

https://doi.org/10.5256/f1000research.19462.r43827

(c) 2019 Rodríguez-Lozano F. This is an open access peer review report distributed under the terms of the Creative Commons Attribution License, which permits unrestricted use, distribution, and reproduction in any medium, provided the original work is properly cited.

\section{Francisco Javier Rodríguez-Lozano}

Cellular Therapy and Hematopoietic Transplant Unit, Hematology Department, Virgen de la Arrixaca Clinical University Hospital, IMIB-Arrixaca, University of Murcia, Murcia, Spain

The manuscript fits into the aim of the journal. The manuscript is well written and the results presented interesting.

I would like to know the search strategy. Inclusion/exclusion criteria.

Minor aspects:

Endodontic perspective: "Given the importance of hypoxia-induced signaling in the early phase of pulp healing we investigated the production of SOST and DKK-1 in dental pulp cells upon treatment with hypoxia or the hypoxia mimetic agent L-mimosine in monolayer, spheroid, and tooth slice cultures". Citation?

Periodontic Perspective: " Dental cementum is a mineralized hard tissue on the surface of root dentin and present either in acellular or cellular form. Defective cementum results in periodontal breakdown, tooth dysfunction, and finally leads to tooth loss." I recommend adding a reference.

Finally, I recommend re-writing the conclusion without citations

Is the topic of the review discussed comprehensively in the context of the current literature?

Yes

Are all factual statements correct and adequately supported by citations? Yes

Is the review written in accessible language?

Yes

Are the conclusions drawn appropriate in the context of the current research literature? Yes

Competing Interests: No competing interests were disclosed.

Reviewer Expertise: endodontics; stem cells; dental stem cells 
I confirm that I have read this submission and believe that I have an appropriate level of expertise to confirm that it is of an acceptable scientific standard.

The benefits of publishing with F1000Research:

- Your article is published within days, with no editorial bias

- You can publish traditional articles, null/negative results, case reports, data notes and more

- The peer review process is transparent and collaborative

- Your article is indexed in PubMed after passing peer review

- Dedicated customer support at every stage

For pre-submission enquiries, contact research@f1000.com 